\title{
Assessment of Wild R. pimpinellifolia L. According to Mineral Content and Bioactive Compounds
}

\author{
Özlem Çakır ${ }^{1 *}$, Berivan Ergen ${ }^{2}$ \\ 1* Bayburt University, Faculty of Engineering, Departmant of Food Engineering, Bayburt, Turkey, (ORCID: 0000-0002-5080-7721), ocakir@bayburt.edu.tr \\ ${ }^{2}$ Bayburt University, Faculty of Engineering, Departmant of Food Engineering, Bayburt, Turkey, (ORCID: 0000-0002-1818-7382), berivankaynak@hotmail.com
}

(First received 27 May 2021 and in final form 5 August 2021)

(DOI: 10.31590/ejosat.943477)

ATIF/REFERENCE: Çakır, Ö. \& Ergen, B. (2021). Assessment of Wild R. pimpinellifolia L. According to Mineral Content and Bioactive Compounds. European Journal of Science and Technology, (25), 644-649.

\begin{abstract}
In this study the characteristics of the fruits of $R$. pimpinellifolia as a naturally grown and wild species in Bayburt was investigated. The antioxidant property of this fruit was determined by using four different methods; DPPH, ABTS, CUPRAC and $\beta$-carotene bleaching method in both water and methanolic extracts. Total phenolic content and phenolic profiles were determined by FCR (Folin-Ciocalteu reagent) method and HPLC, with respect. Additionally mineral contents and some physicochemical properties were analyzed. The antioxidant activities obtained from aqueous extract as $0.56 \mathrm{mmol} \mathrm{TR} / \mathrm{g}$-sample for CUPRAC, $97.02 \%$ for $\beta$-carotene bleaching method, $88.65 \%$ for ABTS and $86.69 \%$ for DPPH. For the methanol extraction antioxidant activities recorded as $0.99 \mathrm{mmol} \mathrm{TR} / \mathrm{g}$-sample for CUPRAC, $95.21 \%$ for $\beta$-carotene bleaching method, $93.43 \%$ for ABTS and $85.21 \%$ for DPPH. Total phenolic compound level was determined as $929.27 \mathrm{mg} \mathrm{GAE} / 100 \mathrm{~g}$ in aqueous extract and that was found to be higher than methanolic extract. The most dominant phenolic compounds in the $R$. pimpinellifolia were detected as chlorogenic acid, vanillic acid and gallic acid. The dominant minerals found in this wild fruit were $\mathrm{K}(12.1688 \mathrm{mg} / \mathrm{ml}), \mathrm{P}(1.3429 \mathrm{mg} / \mathrm{ml})$ and $\mathrm{Mg}(1.1926 \mathrm{mg} / \mathrm{ml})$ whereas $\mathrm{Cr}(0.00001 \mathrm{mg} / \mathrm{ml}) \mathrm{was} \mathrm{minimum}$. Consequently, black rosehip ( $R$. pimpinellifolia) fruit can be suggested to be very good natural nutrient source due to its high content of phenolic compounds and minerals and important antioxidant activity and phenolic.
\end{abstract}

Keywords: R. pimpinellifolia; R. spinosissima; Mineral content; Antioxidant activity; Total phenolic content; Phenolic profile

\section{Yabani Kara Kuşburnu (R. pimpinellifolia L.) Meyvesinin Mineral İçerik ve Biyoaktif Bileșenler Açısından Değerlendirilmesi}

$\ddot{O} z$

Bu çalışmada Bayburt ilinde doğal olarak yetişen yabani R. pimpinellifolia L. meyvesinin genel özellikleri araştırılmıştır. Bu meyvenin antioksidan özellikleri dört farklı yöntem (DPPH, ABTS, CUPRAC ve $\beta$-karoten ağartma) kullanılarak hem su hem de metanol ekstrelerinde belirlenmiştir. Toplam fenolik madde içeriği ve fenolik profili sırası ile FCR (Folin-Ciocalteu ayıracı) metodu ve HPLC yardımıyla analiz edilmiştir. Bunlara ilaveten mineral madde içeriği ve bazı fizikokimyasal özellikleri ele alınmıştır. Su ekstresinde meyve antioksidan seviyeleri CUPRAC yönteminde $0.56 \mathrm{mmol} \mathrm{TR/g-örnek,} \beta$-karoten ağartma yönteminde \%97.02, ABTS metodunda \%88.65 ve DPPH metodunda ise \%86.69 olarak tespit edilmiştir. Metanol ekstresinde ise CUPRAC yönteminde $0.99 \mathrm{mmol}$ TR/g-örnek, $\beta$-karoten yönteminde \%95.21, ABTS metodunda \%93.43 ve DPPH metodunda ise $\% 85.21$ olarak tespit edilmiştir. Toplam fenolik bileşen seviyesi ise sulu ekstresinde $929.27 \mathrm{mg} \mathrm{GAE} / 100 \mathrm{~g}$ olarak belirlenmiş olup bu değer metanol ekstresinde elde edilenden yüksektir. Meyvenin içerdiği fenolik bileşenler arasında en baskın olanların sırası ile klorojenik asit, vanilik asit ve gallik asit olduğu belirlenmiştir. Meyvede bulunan minerallerin arasında en yoğun olanlar sırası ile K $(12.1688 \mathrm{mg} / \mathrm{ml}), \mathrm{P}(1.3429 \mathrm{mg} / \mathrm{ml})$ ve Mg $(1.1926$ $\mathrm{mg} / \mathrm{ml})$ olurken en az bulunan mineralin ise $\mathrm{Cr}(0.00001 \mathrm{mg} / \mathrm{ml})$ olduğu açığa çıkartılmıştır. Sonuç olarak kara kuşburnu meyvesinin (R. pimpinellifolia) sahip olduğu bu özelliklerden dolayı çok iyi bir doğal besin olarak değerlendirilebileceği anlaşılmıştır.

Anahtar Kelimeler: R. pimpinellifolia; R. spinosissima; Mineral madde; Antioksidan aktivite; Total fenolik madde; Fenolik profil

* Corresponding Author: ocakir@bayburt.edu.tr 


\section{Introduction}

Antioxidant contents and other nutritional compounds of the fruits are very important in human health and nutrition. The acid compounds of the fruits are oxidized in the metabolism quickly and do not affect the human body and health negatively. The organic acid compounds interact with heavy metal ions and decrease possible oxidation-catalyzing effects (Savran 1999). On the other hand, fruit salts have a significant role in the diet that depends on their alkaline properties and the sugar-acid ratio is one of the criteria about fruit maturity (Naveed et al. 2015). Besides, these phenolic compounds make important contributions to the taste and astringency of the fruits. They have a significant role in fruit juice producing processes and the surplus of fruit juice and wines (Cemeroglu 2018, Celik et al. 2017).

Many studies emphasize that antioxidant and total phenolic contents of the fruits make them very beneficial and essential objects for healthy nutrition and human metabolism (Guimaraes et al. 2014, da Silva et al. 2019). Especially wild grown fruits have a very significant place in this area. Rosehip and its various types can be thought as leading wild grown fruits (Oz 2016, Alp et al. 2016, Paunovic et al. 2018, Kerasioti et al. 2019).

Rosehip is a wild and natural fruit which and a kind of rose plant that exists in Rosaceae family and belongs to Rosa genus. Rosa L. (Rosaceae) contains nearly 150 sub-species that grow in the northern hemisphere. In addition to its nutrient compounds, most types of rosehip are grown as ornamental plants due to their flowers and fruits (Ercisli 2005). One of the lesser-known and non-cultivated type of rosehip is Rosa pimpinellifolia L. sinonim Rosa spinosissima L., is named as black rosehip in Turkey. $R$. pimpinellifolia consists in a short shrub with an upright or slightly curved form. This plant can extend up to $1-1,5$ meters and its thorn number is very high and has an average of 7-11 oval leaflets. The fruits are hairless with black-purple color and the plant flowers in June and July. It grows in arid and rocky slopes, volcanic rocks or limestone soils at 1200-2750 m altitude. Natural distribution of $R$. pimpinellifolia throughout the world is Northwest, China, South Siberia, North Africa, North America, Asia, Europe and Anatolia (Boyd 2012). Black rosehip is spread into the high mountainous cuttings of Bayburt, Tokat, Gümüşhane, Erzurum, Kars, Van and Ağrı in Turkey (Akkemik 2018).

Although there are many studies in the literature on the antioxidant, mineral matter and total phenolic contents of wild rosehip species grown in Turkey (Murathan et al. 2016, Yildiz et al. 2018, Macit 2018, Oz et al. 2018), there are very few on $R$. pimpinelifolia. Our study differs from previous researches in that it aimed to determine more detailed biochemical properties and mineral matter contents of $R$. pimpinellifolia. In this study, phenolic contents, antioxidant activity, and nutritional properties of $R$. pimpinellifolia fruit gathered from the rustic regions of Bayburt (Turkey) were investigated. Four different methods were performed in antioxidant activity measurement. The physicochemical and pomological properties of the fruit were determined, and the results were analyzed statistically using the measurement parameters.

\section{Material and Method}

Bayburt is a Turkish province situated in the Eastern Black Sea Region. It is located on the $5 \mathrm{~km}$ east of the point where the $41^{\circ}$ East longitude and $41^{\circ}$ North latitude intersect, between 40 $\circ 15^{\prime}$ North latitude and $40^{\circ} 161$ East longitude and its altitude is $1550 \mathrm{~m}$. It is surrounded by high mountains such as Kop and Soganlı (Keskin 2000, Tarkan 1974).

The $R$. pimpinellifolia samples were collected from the rural districts of Sirakayalar village (2000-2120 m altitude) of Bayburt province in autumn season in 2017 and 2018 years. The taxonomic identification of the Rosa pimpinellifolia was done by Abdurrahman Sefalı (Bayburt University, Bayburt, Turkey). They were native wild and never been exposed to particular cultural processes or cultivation. The harvested samples were in the form of fully mature and have a purple-black color. After harvesting, they were carried to the laboratory immediately and some pomological and physiological measurements were made first. Secondly, kernels were stoned out and the hairs were removed quickly. The samples collected from all parts of the plants were stored at $-80{ }^{\circ} \mathrm{C}$ and some of them at $+4{ }^{\circ} \mathrm{C}$ until the other analysis.

In order to determine the physical properties, 20 rosehip fruits were selected randomly and the required measurements were performed for all then average value was calculated. The width and length of the fruit were measured using a digital caliper with $0.01 \mathrm{~mm}$ precision. Fruit mass was measured with a $0.001 \mathrm{~g}$ trebuchet while the determination of fruit volume was made with a water tube. Color measurement of the fruit samples was made by using Minolta CR-300 color determination device. In the results presents the black white (100: white, 0: black), a describes the red green (+: red, -: green) and $b$ describes the yellow green (+: yellow, -: blue) colors.

Water-soluble dry matter content was measured with a digital refractometer (Model Ra 250HE, Kyoto Electroncis Manufactoring Co. Ltd. Japan). The $\mathrm{pH}$ values of the fruits, which were first homogenized with a blender, were measured with Jenco Electronics, 6173 brand $\mathrm{pH}$ meter. During the measurement, the results were calculated after fixing the electrodes for about 1-2 minutes until the results become clearer. Vitamin $\mathrm{C}$ (Ascorbic acid) content, glucose, sucrose, and total sugar were determined with reflectometry measurement device RQflex plus 10 (MERCK, Germany). The water activity of the rosehip samples was examined with the AquaLab brand (Decagon Devices, Inc., Pullman, WA). Approximately $5 \mathrm{~g}$ of the fruit samples were placed in specific plastic containers of the device and measured at $25^{\circ} \mathrm{C}$.

Randomly selected fruits were weighed $3 \mathrm{~g}$ with four repetitions on a sensitive scale and their wet weight was determined. These samples were then dried at $105{ }^{\circ} \mathrm{C}$ until they reached a constant weight and their weights were measured again on a precision balance. After the final weighing taken, the crucible remaining as a result of the dry matter was placed in the ash furnace and gradual burning was performed; 30 minutes at 250 ${ }^{\circ} \mathrm{C}, 30$ minutes at $350{ }^{\circ} \mathrm{C}, 30$ minutes at $450{ }^{\circ} \mathrm{C}$, and finally the temperature was brought to $550{ }^{\circ} \mathrm{C}$. It was continued to burn for about 5-6 hours until the white, gray color appeared. After incineration, the desiccator was cooled for 1 hour and the first weighing was done. It was held again at $550{ }^{\circ} \mathrm{C}$ for 30 minutes and cooled in a desiccator for 1 hour. The process was continued until the difference between weighing 1 and weighing 2 was at least 0.003 .

By following the Meng et al. (2011), $100 \mathrm{~g}$ of the fruit samples were taken randomly from the collected fruits and homogenized by using a blender. $5 \mathrm{~g}$ of homogenized sample and $30 \mathrm{ml}$ of $80 \%$ methanol were added into the centrifuge tube and 
then the mixture is put in an ultrasonic bath for 30 minutes. Later the mixture was centrifuged for gathering the supernatant. After this process, $80 \%$ methanol was added again on to the remaining mixture, waited in the ultrasonic bath for 30 minutes and centrifuged again. This procedure was performed by using water instead of methanol as a solvent in the same way. The extracts were kept in a refrigerator at $-80{ }^{\circ} \mathrm{C}$. After this procedure antioxidant activity and total phenolic content were determined by using a UV spectrophotometer (Shimadzu, UV-1800, Kyoto, Japan). Four different methods were performed to determine the antioxidant activity of the $R$. pimpinellifolia. Firstly, the $\beta$ carotene method was performed and the required calculations were made according to the $\beta$-carotene bleaching Method developed by Kaur and Kapoor (2002). BHA was used as standard material. Secondly, the CUPRAC method was performed according to Apak et al. (2007). In this method $1 \mathrm{~mL} \mathrm{CuCl}_{2}(1.0 \mathrm{x}$ $\left.10^{-2} \mathrm{M}\right)$ and $1 \mathrm{~mL}$ neocuproine alcoholic $\left(7.5 \times 10^{-3} \mathrm{M}\right)$ and $1 \mathrm{~mL}$ of $1 \mathrm{M} \mathrm{NH}_{4} \mathrm{AC}$ buffer ( $\mathrm{pH} 7$ ) solutions were mixed in a test tube and $0,5 \mathrm{~mL}$ sample extraction and $0,6 \mathrm{~mL}$ water were added to the mixture. Absorbance difference was determined after $30 \mathrm{~min}$ at $450 \mathrm{~nm}$. The calibration curve was plotted using trolox (TR), and the antioxidant activity was expressed as trolox equivalent ( $\mathrm{mmol}$ $\mathrm{TR} / \mathrm{g}$ of dry matter). Thirdly, free radical scavenging activity (DPPH) was determined using the method of Gulcin (2005). In this method, the absorbance decrease corresponds to the amount of DPPH solution removed, which indicates the free radical removal activity. Inhibition value was calculated according to the absorbance change results. Fourthly, the TEAC method was performed and required calculations were made according to $\mathrm{Re}$ et al. (1998). The ABTS radical (2,2'-azinobis (3-ethylbezothiazoline 6 sulfonate)) was composed by the reaction between $7 \mathrm{mM}$ ABTS and $2.45 \mathrm{mM}$ potassium persulfate solutions. Afterwards, it was left in the dark at room temperature for 12 hours. Before starting the analysis, the ABTS radical was diluted with ethyl alcohol to reach an absorbance of $0.7 \pm 0.025$ at $734 \mathrm{~nm}$. $1 \mathrm{~mL}$ of ABTS solution was added onto different concentrations of the fruit extracts and incubated for $30 \mathrm{~min}$ in the dark. Absorbance was then read at $734 \mathrm{~nm}$ and inhibition is calculated. To determine the total phenolic compounds FolinCiocalteu method was chosen. Gallic acid is used as standard and the process was performed according to Gulcin et al. (2002). Samples were analyzed by using reverse phase HPLC with the help of a PDA detector. The method of Rodriguez-Delgado et al. (2002) was performed with some little modifications for determining the phenolic profile of the fruit. Calibration curves were composed with the help of gallic acid, chlorogenic acid, vanillic acid, sinapic acid, syringic acid, trans-ferulic acid, pcoumaric acid, 4-hydroxybenzoic acid and caffeic acid standards. Samples were filtered using a $0.4 \mu \mathrm{m}$ filter and placed in $1 \mathrm{~mL}$ vials for analysis. The mineral contents of the fruits were examined in Bayburt University General Research Laboratories Application and Research Center by using ICP-MS device and the results were calculated as ppb and \%. All of the data obtained through these analyzes were subjected to variance analysis with One-Way ANOVA.

\section{Results and Discussion}

There are a few academic studies carried out on $R$. pimpinellifolia probably because it is a lesser-known type of rosehip. Due to this limitation in the literature, some of the results obtained in the current study were compared with those of other rosehip species. The pomological aspects of fruit are important as they define its potential for attraction and visual appreciation. The size, color, shape, brightness and general appearance affects the allure and usage of the fruits. The pomological aspects of the R. pimpinellifolia are presented in the Table 1. It's known that the morphological and biochemical properties of the fruits depend on soil type, soil specifications, genetic aspects, and climatic conditions (Gundogdu et al. 2014). Hence, the investigated physical properties of $R$. pimpinellifolia have some significant differences compared to other rosehip types while some show similarities. For instance, the average length, width, weight of the $R$. pimpinellifolia grown in Van (Turkey) were reported as 27.40 $\mathrm{mm}, 13.60 \mathrm{~mm}$ and $1.95 \mathrm{~g}$, respectively (Dogan and Kazankaya 2006). While the average length of our harvested samples is shorter than these, their width and weight are much more than them.

\section{Table 1. Some physical properties of R. pimpinellifolia}

\begin{tabular}{|c|c|c|c|}
\hline \multirow{2}{*}{$\begin{array}{l}\text { Length }(\mathrm{mm}) \\
\text { Width }(\mathrm{mm}) \\
\end{array}$} & \multirow{2}{*}{$\begin{array}{l}20.7 \pm 1.38 \\
21.77 \pm 1.1 \\
\end{array}$} & \multirow{5}{*}{$\frac{\grave{0}}{8}$} & \\
\hline & & & $L^{*}: 13.04 \pm 2.08$ \\
\hline Weigh $(\mathrm{g})$ & $4.29 \pm 0.27$ & & $\mathrm{a}^{*}: 0.86 \pm 0.81$ \\
\hline Seed Numb. & $18.9 \pm 11.37$ & & \multirow[t]{2}{*}{$\mathrm{b}^{*}: 0.51 \pm 0.17$} \\
\hline Volume (ml) & $4.93 \pm 0.49$ & & \\
\hline
\end{tabular}

Solid content, soluble solid content, ascorbic acid, $\mathrm{pH}$, sucrose, glucose, total sugar, water activity, and the ash content of the fruits was examined as illustrated in Table 2. There are some nonignorable differences between the $R$. pimpinellifolia and other rosehip types. For example, soluble solid state and solid state contents of this fruit are $34.79 \pm 3.4$ and $30.1 \pm 2.46$ while they change between $44.74 \pm 1.17$ to $51.67 \pm 2.30$ (Kazankaya et al. 2005) and 14.27-24.0 (Kasun 2017) for other rosehip types.

The change of water activity, $\mathrm{pH}$ value and the ash content were determined as $0.91 \pm 0.01 ; \quad 4.24 \pm 0.41 ; 3.78 \pm 0.11$; respectively. These parameters were obtained as $0.692-0.716$, $3.56-3.61$ and $2.61 \%-3.13 \%$, respectively by Kasun (2017). Compared with this study, the results of $R$. pimpinellifolia have higher $\mathrm{pH}$ value and water activity and lower ash content ratio.

Table 2. Some chemical properties of $R$. pimpinellifolia

\begin{tabular}{l|l}
\hline Solid state rate (\%) & $34.79 \pm 3.4$ \\
\hline Soluble solid content (SSC \%) & $30.1 \pm 2.46$ \\
\hline Ascorbic asid (vitamin C) g/l & $828.67 \pm 56.01$ \\
\hline $\mathrm{pH}$ & $4.24 \pm 0.41$ \\
\hline Sucrose (mg/L) & $146.67 \pm 41.88$ \\
\hline Glycose (mg/L) & $79.33 \pm 15.14$ \\
\hline Total sugar (mg/L) & $578 \pm 30.61$ \\
\hline Water activity & $0.91 \pm 0.01$ \\
\hline Ash content $(\%)$ & $3.78 \pm 0.11$ \\
\hline
\end{tabular}

The data obtained by four different methods, namely DPPH, ABTS, CUPRAC, $\beta$-carotene bleaching method, applied to determine the antioxidant activity of the studied fruit are presented in Table 3. Free radical scavenger activity of antioxidants on DPPH appears with the decrease of absorbance level (Gulcin et al. 2004). Antioxidant activity is determined as $86.69 \%$ and $85.21 \%$ in water and methanol extracts in performing the DPPH method. By the $\beta$-carotene bleaching method, it was found $97.02 \%$ in water and $95.21 \%$ in methanol extract. The value 
of the BHA which was used as standard is $93.76 \%$. Antioxidant activity of the fruit is higher than the value of BHA. The results determined in aqueous extract were found higher than those in methanol (Macit 2016, Oz 2016). According to the results of DPPH and $\beta$-carotene bleaching methods, the antioxidant activity of $R$. pimpinellifolia is a bit higher than Rosa canina and conform with the previous results (Fattahi et al. 2012, Yolcu 2010, Nadpal et al. 2016, Mavi et al. 2004).

Table 3. Bioactive properties of $R$. pimpinellifolia

\begin{tabular}{|c|c|c|c|}
\hline Extract & Aqueous & Methanolic & Significance \\
\hline $\begin{array}{l}\text { Total Phenolic } \\
\text { compounds } \\
\text { (mg GAE/100g) }\end{array}$ & $929.27 \pm 14.41$ & $743.5 \pm 21.21$ & $* *$ \\
\hline DPPH $(\%)$ & $86.69 \pm 0.06$ & $85.21 \pm 0.05$ & $* *$ \\
\hline ABTS (\%) & $88.65 \pm 0.57$ & $93.43 \pm 1.12$ & $* *$ \\
\hline $\begin{array}{l}\text { CUPRAC } \\
(\mathrm{mmolTR} / \mathrm{g}- \\
\text { sample) }\end{array}$ & $0.56 \pm 0.33$ & $0.99 \pm 0.20$ & - \\
\hline$\beta$ - karoten $(\%)$ & $97.02 \pm 0.03$ & $95.21 \pm 0.20$ & $* *$ \\
\hline
\end{tabular}

ABTS and CUPRAC methods were also used to determine antioxidant activity. Antioxidant activity was determined as $88.65 \%$ and $0.56 \mathrm{mmolTR} / \mathrm{g}$-sample in aqueous extract and $93.43 \%$ and $0.99 \mathrm{mmolTR} / \mathrm{g}$-sample in methanol extract. Antioxidant activity was found to be higher in methanol extract in both methods. The results are very close to the antioxidant activity of trolox, which was used as standard material. That means $R$. pimpinellifolia fruit has a very high antioxidant activity level. The antioxidant values of $R$. pimpinellifolia were reported before as $71.81 \pm 7.66 \mathrm{mgTEAC} / \mathrm{mL}$ and $39.15 \pm 5.44 \mathrm{mgTEAC} / \mathrm{mL}$ in methanol used ABTS and CUPRAC methods, respectively (Macit 2018). Phenolic compounds are thought to be the most important phytochemicals that provide antioxidant activity properties to the plants (Pizzale et al. 2002, Gulcin et al. 2004, Mavi et al. 2004, Yolcu 2010, Fattahi et al. 2012, Nadpal et al. 2016,). Total phenolic content of black rosehip fruit was determined as 929.2 $\mathrm{mg}$ GAE/100g in aqueous extract and $743.5 \mathrm{mg}$ GAE/100g in methanol extract. This phenomenon was measured as 15226.32$41845.96 \mathrm{mgkg}^{-1}$ (in aqueous extract) (Yolcu 2010), $143.1 \pm 5.25$ $\mathrm{mg}$ of GAE/g (Barros et al 2011), 2.59-5.09 $\mathrm{mg}^{\circ} \mathrm{GAEg}^{-1}$ (Su et al. 2007), 815.5 mg GAE/100g (Yoo et al. 2008) and 5.42-8.21 mg GAE $\mathrm{mL}^{-1}$ (Ghazghazi et al. 2010) for rosehip fruit. The total phenolic content of $R$. canina and $R$. pimpinellifolia were determined as $225.65 \pm 2.50 \mathrm{mg} \mathrm{GA} / 100 \mathrm{~g}$ and $176.4 \pm 2.71 \mathrm{mg}$ GA/100g respectively (Fattahi et al. 2012). The values obtained in this study are much higher than those relative to the previous studies.

The phenolic profile of the fruit was determined by checking its water and methanol extracts using HPLC (Table 4). Phenolic profile was determined as chlorogenic acid, vanillic acid, gallic acid, caffeic acid in aqueous extraction and vanillic acid, chlorogenic acid, gallic acid, syringic acid, caffeic acid in methanol extraction. In the literature review, no study was found enough exhaustive to be considered for the comparison.
Table 4. HPLC results with water and methanol extraction

\begin{tabular}{lll}
\hline \multicolumn{1}{c}{ Phenolic Acid } & \multicolumn{1}{c}{$\begin{array}{c}\text { Aqueous extract } \\
\text { (ppm) }\end{array}$} & \multicolumn{1}{c}{$\begin{array}{c}\text { Methanolic extract } \\
\text { (ppm) }\end{array}$} \\
\hline Gallic acid & 28.674 & 25.474 \\
\hline 4-Hydroxibenzoic acid & nd & nd \\
\hline Chlorogenic acid & 53.296 & 52.820 \\
\hline Vanillic acid & 49.443 & 60.856 \\
\hline Caffeic acid & 4.277 & 3.218 \\
\hline Syringic acid & nd & 10.046 \\
\hline p-Coumaric acid & nd & nd \\
\hline Trans-Ferulic acid & nd & nd \\
\hline Synapic acid & nd & nd \\
\hline
\end{tabular}

nd: not determined

Information on the mineral content is presented in Fig. 1. Few minerals which are not seen on the figure are also investigated in the $R$. pimpinellifolia but no findings and conclusions regarding these elements have been reached. They are Fe, Li, Be, B, Ga, As, $\mathrm{Se}, \mathrm{Ag}, \mathrm{In}, \mathrm{Sn}, \mathrm{Sb}, \mathrm{Pt}, \mathrm{Au}, \mathrm{Ru}, \mathrm{Hg}, \mathrm{Tl}$ and $\mathrm{Bi}$. R. pimpinellifolia fruit was found to be rich in mineral content just like $R$. canina which is the other type of rosehip. The potassium content was the highest among the considered minerals with a concentration of $12.1688 \mathrm{mg} / \mathrm{ml}$, followed by $\mathrm{P}, \mathrm{Mg}, \mathrm{Ca}, \mathrm{Na}$ and $\mathrm{Zn}$. The lowest amount of mineral matter was assigned to $\mathrm{Cr}$ with a concentration of $9.72 \mathrm{ppb}$. The content of potassium in the fruits of different rosehip species was reported in the range of 4200-1900 ppm (Kovacs et al. 2004), and the average potassium content of rosehip fruits determined as 9140 ppm (Kazaz et al. 2009). It is reported that the found concentrations can be ordered from high to low as follows: $\mathrm{K}, \mathrm{Mg}, \mathrm{P}, \mathrm{Mn}, \mathrm{Fe}, \mathrm{Cu}$, and $\mathrm{Zn}$ for $R$. canina $(\mathrm{Oz}$ et al. 2018). As it can be noticed, the results found in this study and the works in literature are similar in terms of potassium and phosphorus (Oz et al. 2018). However, the content of black rosehip fruits was found to be higher $\mathrm{K}$ and $\mathrm{P}$ amounts.

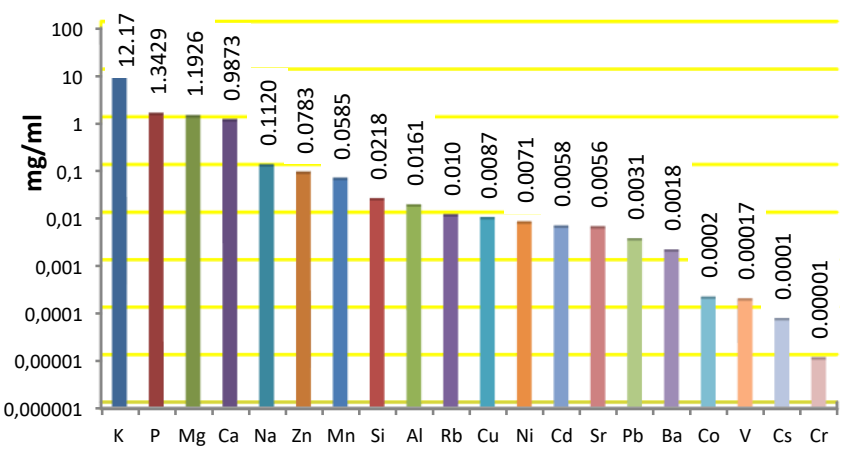

Figure 1. R. pimpinelifolia fruit mineral content

\section{Conclusion and Recommendations}

$R$. pimpinellifolia which is also called black rosehip, is a type of rosehip that is not very common and kept unexplored, therefore scientific studies carried out on this fruit are very few. For this reason, the data achieved by this study can make very important contributions to the literature. The main conclusions are presented as follows.

This fruit has some differences in terms of the general physical structure when compared to the commonly known red 
rosehip species. In this respect, it is determined that black rosehip has an important potential in the food industry to convert products with different properties. When the available color values and the characteristics are taken into consideration, it can be deduced that this fruit can have a big importance in the food sector and be evaluated in the controversial field of food dyes. The use of this fruit instead of artificial and harmful food dyes, especially in products that appeal to children, will be an important step for healthier food products.

It was concluded that the amount of dry matter is relatively low and the amount of dry matter soluble in water is relatively high, but it overlaps with some values. Additionally, the black rosehip can be easily evaluated both in the food industry and domestic uses thanks to the chemical properties presented in this study. It is also recommended to be used as herbal tea, syrup or marmalade for disease prevention.

R. pimpinellifolia fruit has a mineral matter similar to the one present in the red rosehip, Rosa canina. $75.96 \%$ of the amount of mineral matter is constituted mostly by the potassium element. The amounts of phosphorus, magnesium, calcium are $8.38 \%$, $7.44 \%, 6.16 \%$ respectively. The other minerals ( $\mathrm{Na}, \mathrm{Zn}, \mathrm{Al}, \mathrm{Mn}$, $\mathrm{Cu}, \mathrm{Cd}, \mathrm{Ni}, \mathrm{Sr}, \mathrm{Rb}, \mathrm{Ba}, \mathrm{Pb}, \mathrm{V}, \mathrm{Co}, \mathrm{Cs}, \mathrm{Cr}, \mathrm{Si}$ ) were found having very small amounts with a total determined as $2.06 \%$. This study will be the first one since there is no study on the mineral content of black rosehip fruit in the literature. Given the rich and nutritional mineral amount contained in this fruit, it is supposed to be the subject of new and various studies.

The results of our study show that $R$. pimpinellifolia fruit has an effective content in terms of total antioxidant activity. The antioxidant activity of this fruit was found to be similar to some synthetic antioxidants and even higher than them according to the results of analyzes. Therefore, it may be recommended to expand its consumption. The components of the fruit show different properties in different extractions. Considering this situation, it is thought that it may be possible to encounter different results according to extraction methods.

According to the chromatogram results, chlorogenic acid was defined as basic phenolic acid in aqueous extraction of black rosehip fruit and the ranking was as follows: chlorogenic acid> vanillic acid $>$ gallic acid $>$ syringic acid $>$ caffeic acid. In the methanol extraction of the fruit, the basic phenolic substance was determined as vanillic acid. The ranking was found to be vanillic acid $>$ chlorogenic acid $>$ gallic acid $>$ syringic acid $>$ caffeic acid.

As a result, it is concluded that it will be very beneficial to determine the amount and variety of this plant which grows naturally in many locations and to increase the possibilities of its economic and social evaluation. $R$. pimpinellifolia fruit has an effective content in terms of total phenolic substance, phenolic substance profile, and total antioxidant activity and also contains significant mineral substance

\section{References}

Akkemik, Ü., 2018. Türkiye'nin Doğal-Egzotik Ağaç ve Çalıları. Orman Genel Müdürlüğü Yayınları, Ankara. 684.

Alp, S., Ercisli, S., Jurikova, T., Cakir, O. and Gozlekci, S., 2016. Bioactive content of rose hips of different wildly grown Rosa dumalis genotypes. Notulae Botanicae Horti Agrobotanici Cluj-Napoca, 44(2):472-476.

Apak, R., Güçlü, K., Demirata, B., Özyürek, M., Çelik, S. E., Bektaşoğlu, B., Berker, K.I. and Özyurt, D., 2007. Comparative evaluation of various total antioxidant capacity assays applied to phenolic compounds with the CUPRAC assay. Molecules, 12:1496-1547.

Barros, L., Carvalho, A.M. and Ferreira, C.F.R., 2011. Exotic fruits as a source of important phytochemicals: improving the traditional use of Rosa canina fruits in Portugal. Food Research International, 44:2233-2236.

Boyd, P.D.A., 2012. Rosa spinosissima - aspects of its natural history and associations with people from prehistory to the present day. World Federation of Rose Societies 12th International Heritage Rose Conference, Sakura, Japan.

Celik, F., Gundogdu, M., Alp, S., Muradoglu, F., Ercisli, S., Gecer, M. and Canan, I., 2017. Determination of phenolic compounds, antioxidant capacity and organic acids contents of Prunus domestica L., Prunus cerasifera Ehrh. and Prunus spinosa L. fruits by HPLC. Acta Chromatographica, 29(4):507-510.

Cemeroglu, B. S. 2018. Meyve ve sebze işleme teknolojisi, 7th edn. Bizim Büro Basımevi, Ankara

da Silva. A. P., Spricigo, P. C. \& Purgatto, E., 2019. Volatile compounds determined by spme-gc, bioactive compounds, in vitro antioxidant capacity and physicochemical characteristics of four native fruits from South America. Plant Foods Human Nutrition, 74, 358-363.

Dogan, A. and Kazankaya, A., 2006. Fruit properties of rose hip species Grown in Lake Van basin (Eastern Anatolia Region). Asian Journal of Plant Science, 5, 120-122.

Ercisli, S., 2005. Rose (Rosa spp.) germplasm resources of Turkey. Genetic Resource Crop Evaluation, 52, 787-795.

Fattahi, S., Jamei, R., and Sarghein, S. H., 2012. Antioxidant and antiradical activities of Rosa canina and $R$. pimpinellifolia fruits from fest Azerbaijan Iran. Journal of Plant Physiology, 2(4): 523-529.

Ghazghazi, M., Miguel, M.G., Hasnaoui, B., Sebei, H., Ksontini, M., Figueiredo, A.C., Pedro, L.G. and Barroso, J.G., 2010. Phenols, essential oils and carotenoids of Rosa canina from Tunisia and their antioxidant activities. African Journal of Biotechnology, 9(18):2709-2716.

Guimaraes, R., Barros, L., Calhelha, R. C., Carvalho, A. M. and Queiroz, MJRP., 2014. Bioactivity of different enriched phenolic extracts of wild fruits from northeastern Portugal: a comparative study. Plant Foods Human Nutrition, 69, 37-42.

Gulcin, I., 2005. The Antioxidant and radical scavenging activities of black pepper (Piper nigrum) seeds. International Journal of Food Science Nutrition, 56, 491-499.

Gulcin, I., Mshvildadze, V. and Gepdiremen, Elias R., 2004. Antioxidant activity of Saponins isolated from ivy: a-hederin, hederasaponin-c, hederacolchiside e and hederacolchiside F. Planta Medica, 70:561-563.

Gulcin, İ., Oktay, M., Kufrevioglu, I., and Aslan, A., 2002. Determination of antioxidant activity of lichen Cetraria islandica (L) Ach. Journal of Ethnopharmacology, 79(3): 325329. 
Gundogdu, M., Ozrenk, K., Ercisli, S., Kan, T., Koda, O. and Hegedus, A., 2014. Organic acids, sugars, vitamin C content and some pomological characteristics of eleven hawthorn species (Crataegus spp.) from Turkey. Biological Research, $47,1-5$.

Kasun, S., 2017. Determination of total phenolic content, phenolic composition, antioxidant capacities and some physicochemical features of rosehip (Rosa canina) and hawthorn (Crataegus orientalis) wild fruits growing in the region of Tunceli. Dissertation, Tunceli University, Tunceli, 115.

Kaur, C. and Kapoor, H. C., 2002. Anti-oxidant activity and total phenolic content of some asian vegetables. International Journal of Food Science and Techology, 37(2):153-161.

Kazankaya, A., Turkoglu, N., Yilmaz, M. \& Balta, M. F., 2005. Pomological Description of Rosa canina Selections from Eastern Anatolia, Turkey. International Journal of Botany, 1, 100-102.

Kazaz, S., Baydar, H., and Erbas S. 2009. Variations in chemical compositions of Rosa damascena Mill. and Rosa canina L. fruits. Czech Journal of Food Science, 27(3): 178-184.

Kerasioti E, Apostolou A, Kafantaris I, Chronis K, Kokka E, Dimitriadou C, Tzanetou EN, Priftis A, Koulocheri SD, Haroutounian SA, Kouretas D. and Stagos D., 2019. Polyphenolic composition of Rosa canina, Rosa sempervivens and Pyrocantha coccinea extracts and assessment of their antioxidant activity in human endothelial cells. Antioxidants (Basel). 6:8(4):92.

Keskin, T., 2000. İl Oluşunun 10. Y1lında Bayburt Tarihi, Bayburt Valiliği Yayınları, Bayburt, s.1

Kovacs, S., Facsar, G., Laszlo, U. \& Toth, M., 2004. Phenological, morphological characteristics of some rose species found in Hungary. Acta Horticulture, 690, 71-76.

Macit, M., 2018. Determination of amounts and bioefficacy of phenolic compounds in roots of Rosa canina L. and Rosa pimpinelifolia Dissertation, İstanbul University, İstanbul, 92.

Mavi, A., Terzi, Z., Ozgen, U., Yildirim, A. and Coskun, M., 2004. Antioxidant properties of some medicinal plants: Prangos Ferulacea (Apiaceae), Sedum Sempervivoides (Crassulaceae), Malva Neglecta (Malvaceae), Cruciata Taurica (Rubiaceae), R. pimpinellifolia (Rosaceae), Galium verum subsp. (Rubiaceae), Urtica dioica (urticaceae). Biological and Pharmaceutical Bulletin, 27(5):702-705.

Meng, J., Fang, Y., Zhang, A., Chen, S., Xu, T., Ren, Z., Han, G., Liu, J., Li, H., Zhang, Z. and Wang, H., 2011. Phenolic content and antioxidant capacity of Chinese raisins produced in Xinjiang province. Food Research International, 44, 2830 2836.

Murathan, Z. T., Zarifikhosroshahi, Kafkas, E. and Sevindik, E., 2016. Characterization of bioactive compounds in rosehip species from east Anatolia region of Turkey. Italian Journal of Food Science, 28, 314-325.

Nadpal, J.D., Lesja, M., Sibul, F.S., Anac`kov, G T., C`etojevic,' -Simin D.D., Mimica-Dukic, N.M. and Beara, I.N., 2016. Comparative study of biological activities and phytochemical composition of two rose hips and their preserves: Rosa canina L. and Rosa arvensis Huds. Food Chemistry, 192, 907-914.

Naveed, A., Farooq, A. and Anwar-ul-Hassan, G., 2015. Essential Oils in Food Preservation, Flavor and Safety. In: Victor R (ed) Rose Hip (Rosa canina L.) oils, 1st edn. Academic Press, Elsevier, England. 76, 667-675.

Oz, M., 2016. The analysis of essential oil and biological activities from the flower, leaf, stem and fruit of rosehip species Rosa pimpinelifolia and Rosa canina L. Dissertation, Karadeniz Technical University, Trabzon, 192.

Oz, M., Baltac1, C. and Deniz, I., 2018. The Analysis of Sugar and Vitamin C in Rosehip (Rosa canina L.) and Black rosehip (Rosa pimpinelifolia) Fruits of Gümüşhane Region. Gümüşhane University Journal of Science and Technology Institute, 8(2):284-292.

Paunovic, D., Kalusevi, A., Petrovic, T., Urosevic, T., Djinovic, D., Nedovic, V. and Popovic-djordjevic, J., 2018. Assessment of chemical and antioxidant properties of fresh and dried rosehip (Rosa canina L.). Notulae Botanicae Horti Agrobotanici Cluj-Napoca, 47(1):108-113.

Pizzale, L., Bortolomeazzi, R., Vichi, S., Uberegger, E. and Conte, L.S., 2002. Antioxidant activity of sage (Salvia officinalis and $\mathrm{S}$ fruticosa) and oregano (Origanum onites and $\mathrm{O}$ indercedens) extracts related to their phenolic compound content. Journal Science Food and Agriculture, 82, 16451651.

Re, R., Pellegrini, N., Proteggente, A., Pannala, A., Yang, M. and Rice Evans, C., 1998. Antioxidant activity applying an improved ABTS radical cation decolorization assay. Free Radical Biology and Medicine, 26, 1231-1237.

Rodriguez-Delgado, M. A., Malovana, S., Perez, J. P., Borges, T. and Garcia Montelongo, F. J., 2001. Separation of phenolic compounds by high-performance liquid chromatography with absorbance and fluorimetric detection. Journal of Chromatography A, 912(2):249-257.

Savran, H. S., 1999. Organic acid profile of pomegranate juice. Dissertation, Ankara University, Ankara, 46.

Su, L., Yin, J. J., Charles, D., Zhou, K., Moore, J. and Yu, L. L., 2007. Total phenolic contents, chelating capacities, and radical-scavenging properties of black peppercorn, nutmeg, rosehip cinnamon and oregano leaf. Food Chemistry, 100 (3): 990-997.

Tarkan, M. T., 1974. Bayburt'un Ekonomik Olanakları ile Bu Olanakların Kalkınma Alanındaki Önem Dereceleri. Edebiyat Fakültesi Araştırma Dergisi, 5, 83-88.

Yildiz, H., Cakır, O., Karatas, N., Oguz, H. I, Ciniviz, M. and Sasmaz, H. K., 2018. Polyphenol profile and antioxidant activity of some wild fruit in Turkey. The 4th Int. Symposium on Traditional Foods from Adriatic to Caucasus, Kyrenia / Northern Cyprus.

Yolcu, H., 2010. Changes of antioxidant properties in rosehip pulp, Dissertation, Ondokuz Mayıs University, Samsun, 87.

Yoo, K. M., Lee, C. H., Lee, H., Moon, B. and Lee, C. Y., 2008. Relative antioxidant and cytoprotective activities of common herbs. Food Chemistry, 106(3):929-936. 